\title{
Searching for Mexico's Lost Labor Subject: Historical and Biographical Milestones in the Constitution of the Sociology of Work in Mexico
}

\author{
Enrique de la Garza Toledo, Metropolitan Autonomous Museum of Mexico
}

\begin{abstract}
This essay aims to weave together salient moments in the development of the Mexican labor movement, the reorganization of the economy and production starting in the 1980s, the development of Sociology of Work in Mexico, and snapshots from my own autobiography. The biographical perspective helps to illustrate a few parallel lives that formed part of a collective intellectual and political movement in the period under analysis. Our perspective is that the macro shifts are not reducible to the individual events of which they are composed; they may affect individuals' actions, but they do not determine them. Peoples' actions are located within structures, but they require subjectivity to acquire meaning and orient said actions. At least that is how we have believed ourselves to be living all these years.

The period of our study begins in the 1970s with the end of the importsubstitution period in the Third World, the emergence of a powerful workers' movement in Mexico that questioned corporatist unions and political structures and lasted until the early 1980s when the reorganization of the economy and model of production in large companies happened. This moment also marked the beginnings of today's Sociology of Work in Mexico, which broke with previous conceptions focused on the study of workers' movements and with Dependency theories predominant in Latin American social theory. We found ourselves immersed in these processes, suffering the changes while at the same time, as a new generation of scholars emerged, attempting to exercise influence on union conceptions of labor. This history is the subject of the current essay.
\end{abstract}

KEY WORDS

labor movement, Latin America, Mexico, New Labour Studies, Sociology of Work

\section{The End of Import Substitution in the 1970s}

The economic model known as import substitution originated in the post-World War II period in countries such as Mexico as a type of Keynesian adaptation to underdevelopment. This model prescribed a strong state presence in the economy - as owner of companies; regulator of the economic process, including intervening in labor 
relations, and setting workers' wages - as a spur to internal market demand and a source of political legitimacy. The model drove the transition from an economy based on the primary sector to one of industrial production. Industry was protected from external competition by the state through import tariffs, soft credits for industry, and price controls in agriculture that benefited industry. It was an industrial production directed toward the internal market, promoting the production of consumption goods more than capital goods. The model also implied a broad collaboration among managers, unions, and the state - initially also including rural farmers' organizations - to negotiate and establish a complex arrangement of legal and extralegal state guarantees. These guarantees would maintain unions' monopoly on representation, including redistributive policies, collective hiring agreements, and social security benefits, in exchange for the unions' support for electoral and economic policy and their participation in the governing party. All of this was accompanied by oligarchy inside the unions and the authoritarian political system. This model fell into crisis in the 1970 s and was replaced in the 1980 s by the so-called neoliberal ${ }^{1}$ model (De la Garza 1988).

I was born in a suburb of Monclova, Coahuila, a state on the US border, around the time when the region's import-substitution industrial development had just begun to take off (the end of the 1940s), spurred by Altos Hornos de México, the country's most important steel company. My childhood was characterized by a transition from a rural town to a bedroom community inhabited by the new industrial working class of Monclova. I attended the Ignacio Zaragoza public elementary school, and we lived very close to a neighborhood where most of my childhood friends were sons or brothers of workers newly employed at the big Monclova plants (25,000 steel workers in one plant and many more in the steel, mining, and metal industry clusters). Together we formed Los Potas, a gang of kids who imagined fighting battles and returning to life in the wild, in intimate contact with nature. The drastic transformation brought about by the rapid industrialization process (1950s to19 70s) produced in much of the population a sort of 'how green was my valley' syndrome, reminiscent of the marvelous film by John Ford. Perhaps these early images and friendships are the reason I have always identified with the poor and felt a sense of indignation toward powerful people.

When I entered sixth grade, we moved to a better neighborhood located just off the town's main square. The trauma of leaving my friends and my neighborhood, and my rejection of rich people never disappeared. In those years the closest secondary school was Monclova Junior High No. 24, an excellent public school with a great staff of teachers. Home was also a lively place of reading and learning. My family was always discussing history and politics, subjects my father was passionate about from a liberal, anti-Catholic Church perspective and with a moderate socialist orientation. Around that time I began to join Masonic youth groups, seeking to politicize other young people. One night we were handing out fliers in opposition to the priest's plan to use profits from the town fair to rebuild the church instead of providing social services. The police caught us, and that was the first time I went to jail for 'political motives'. Those were the years of Fidel Castro's triumph in Cuba - an event from which I took great inspiration.

After junior high, I enrolled at Senior High School No. 2 at the University of Nuevo Leon in Monterrey, an important industrial city since the late 19th century. I lived in boarding houses, which for a long time I considered to be the best places to live. I was 
already on a path toward creating a link between my life and politics. The first thing I did in Monterrey was visit my brothers at the Masonic Lodge. I arrived with a book by Benito Juarez - a liberal nineteenth century leader - under my arm, and they asked me why I was reading bourgeois authors. The Masonic Lodge was dominated by the Spartacists, a radical communist group. One night during the presidential electoral campaign of Díaz Ordaz of the ever-ruling Institutional Revolutionary Party (PRI), a group of high school friends and I changed the words on a huge banner from 'Nuevo Leon for Díaz Ordaz' to 'Death to Díaz Ordaz'. The judicial police arrested me at the boarding house where I was staying, and that was the second time I went to jail.

After senior high school, I wanted to study philosophy, but my entire family conspired to persuade me otherwise. Engineering was the most legitimate profession in this highly industrial zone. I didn't have the strength to challenge them, so I enrolled in the School of Chemical Sciences at the University of Nuevo Leon to study Chemical Engineering. I continued my political activities there, and the student movement became increasingly radicalized, first around the struggle against an increase in student fees and then in support of the 1968 student movement. I actively participated in that movement from Monterrey, and you could say I was one of the movement's leaders. Upon completing my degree, I won an important academic award that immediately opened doors to companies offering me tempting positions. Nevertheless, I wasn't interested in accepting any of the offers, given my decision to continue in the academic world as a university professor and my political position in favor of workers.

The student movements of this era began in the 1960s, well before 1968. Regardless of their initial demands, students clashed frequently with the authoritarian State and suffered repression by the police, the army, and the law. The great movement of 1968, which involved almost all of the country's public universities as well as the most important private universities, was thus preceded by many actions building up to it. This movement was still a peaceful effort to promote democratic freedoms. It was initially made up solely of students, a population that was radicalized as a result of the repression unleashed against them. Some believed that the country could not be transformed by peaceful means, given the authoritarianism of the governing regime. Those groups began to form the urban guerrilla movements that operated in Mexico for the next decade (1970s), whose organizers and primary social base were made up of students. Another segment of the student movement affirmed that the transformation of the country should be achieved through mobilizing the workers, who were firmly controlled by corporate unions, the traditional peasant, in a situation similar to the workers; and the poor, urban sectors living in the socalled 'popular neighborhoods'. Many students went to the factories, peasant communities, and popular neighborhoods, where they formed organizations charged with left-wing ideologies, most often Marxist. We established this movement and participated from our position as students in Monterrey. The defeat of the students in 1968 did not put an end to student activism, which at times continued in other movements in other areas of the country or transformed into attention toward the countryside or perhaps efforts to join the guerrilla fighters. The student participants in the university conflicts of the 1960s, as organizers, occasionally as direct leaders, and in other cases as ideologues, thereby made an important contribution to the labor, peasant, and 'popular' movements of the 1970s. It is difficult to find a period after the 1910-1920 Mexican Revolution more conflictual, 
animated, and widespread than the 1970s. The point of ignition was the authoritarianism that permeated all levels of government and the state repression of autonomous political, union, peasant, and popular projects. The radicalized elements of the organizations that emerged from this era leaned toward Marxism in varying forms (inspired by Guevara, Trotsky, or Mao, among other tendencies). These were also the years of the Marxist guerrilla fighters in Latin America inspired by the Cuban Revolution (De la Garza 1984).

When a new phase of struggle began at the University of Nuevo Leon, focused on democratizing the rector's office, I transferred to Mexico's National Autonomous University (UNAM), where I entered a Master's Program in Chemical Engineering. Soon after my arrival in Mexico City, the June 10th massacre took place - a criminal attack by President Echeverría against students who dared, after 2 October 1968, to return to the streets to protest. Many of them died before my eyes. After the June 10th massacre, many activists decided that the path to transforming the political regime was armed struggle, and they joined the guerrillas. My old comrades from the School of Chemistry at the University of Nuevo Leon followed this path.

I participated in creating the UNAM committees that took up the struggles of 1968 in the midst of the guerrillas' struggles and of the terror unleashed by Nassar Haro, assistant director of the Federal Security Police. I continued my education in increasingly specialized areas of engineering, eventually obtaining a scholarship to McMaster University in Canada. So, I went North to continue my graduate studies. Everything at that university was order, resources, and studies, but Canada turned out to be too peaceful a country for me. Through my UNAM friends who had obtained positions as university professors in Puebla, a southern Mexican state with one of the highest levels of university conflicts, I received an offer to teach at the School of Chemical Engineering. I left my studies in Canada and went to live in Puebla. The Left had just gained a position of power at the university, but there were still significant bastions of the Catholic Church-influenced Right. My first day as a professor at that university was literally a 'trial by fire'. I saw a line of armed students heading toward the School of Architecture. Someone handed me a gun and told me to follow them to force out the activists from the Frente Universitario Anticomunista (AntiCommunist University Front). During those years, any and all disagreements at that university were resolved at gunpoint, and at gunpoint my group was forced out. I then went back to my cherished University of Nuevo Leon, now as a professor.

But, I arrived at a very bad time. The Liga 23 de Septiembre, the foremost guerrilla group in the 1970s, had just assassinated Eugenio Garza Sada, a top business leader. The Monterrey Group (a powerful business organization) and the White Brigade led by Nassar Haro unleashed a witch hunt, in which I was kidnapped and tortured. I almost didn't make it out alive and was only released because of my father's determination and protests organized on our behalf in a number of states. Even after I was freed, the police monitored my every move and threatened to kidnap me again. Those were the years of the dirty war when many people disappeared and were never seen again. I had no choice but to leave the area. I saw an announcement from Colegio de México, the top social science teaching and research institution in Mexico, and although I didn't have any formal education in Sociology, I was able to pass the admissions exam and subsequently earn my doctorate in Sociology at the Colegio de México. I studied and learned a great deal there, trying to understand the reasons behind our defeats. The influence of Professor Hugo Zemelman, a 
Marxist Chilean exile, was definitive in transforming my thinking from rudimentary Marxism to issues related to the constitution of subjects, especially those critical of positivistic and structuralistic social science approaches.

Amidst this nation-wide state of agitation, I prolonged my stay at the country's universities for the next ten years, obtaining grants to live on and accumulating degrees and titles. But, by the early 1980s, it had become clear that the independent workers' movement of the 1970s was in freefall, having suffered numerous defeats and forms of repression. Union corporativism had received a thrashing, but the great pact between the unions and the State continued and was reconstituted. The same occurred with the peasant and popular movements, while the student movement was a thing of the past. This feeling of defeat and the need to better understand what had happened, in the context of the massive economic crisis that began in the 1970s which led the way to the fundamental transformations of neoliberalism, led me to the University of Rome in Italy. Once again, with the pretext of completing my doctoral thesis, I was able to secure a grant. This was the second of my four extended stays abroad.

What I found in Italy was a labor movement that did not know what to do either when Fiat posed a massive reorganization. A national strike was unable to stop it, and the Italian working class would not attempt such a move again for another twenty years. The new extra-parliamentary left of the 1970s was also in crisis. The conflicting groups dissolved or set up competing strongholds in narrow urban spaces, and the student movement ceased to exist. The study of the Italian theoreticians and my own observation of this scenario - which in the 1970s had been one of the most creative - led me to conclude that we were at a historical turning point: that the labor subjects of the Keynesian period had fallen into decadence, and it was unclear whether others could take their place. In the meantime, a period of reaction and discord was likely in the unions. When I returned to Mexico, I broke my ties with the radical political groups with which I had been associated in different ways for the last ten years, and I began to work as a professor at the recentlyformed Metropolitan Autonomous University (UAM) in Mexico City.

At this moment, the unions made their final attempt to put a halt to the impending neoliberal path taking hold in the country, as elsewhere. They attempted a general strike in 1983, including the corporate unions, who were concerned that the imminent reforms would jeopardize their positions, in particular vis-à-vis the State. This process of dismantling of the old labor class, the labor class of import substitution model, defeated

politically and restructured in the labor processes in the 80 s, for us was the beginning of looking for new labor subjects.

\section{The Beginnings of Neoliberalism (the 1980s)}

As I mentioned, upon my return from Italy at the beginning of the 80s I assumed a post as professor at the Metropolitan Autonomous University (UAM), a new public university that served as refuge for several student activists from the 1970s, who filled the positions on the university's team of professors.

A group of colleagues and I took on the task of investigating how workers had been studied in Mexico in the preceding years. In a survey of some 10,000 studies, we found that 
the large majority consisted of histories of workers' movements, mostly in the present, but including historical studies as well. The central concept addressed was corporativism, not in the Schmitter (1974) version but rather based on local reflections. The question of greatest concern in relation to Mexican corporativism was State control through organizations and how to make the worker movement independent, as the movement itself attempted to do in the 1970s. But the analyses of these movements excessively emphasized the ideologies and actions of leadership, such that the workers appeared as a mere backdrop. Castoriadis (1979) would have likened this rendition of history to 'the machinists of the engine of the history'.

On the other hand, there were quantitative, socio-demographic studies concerned with informality or marginality and an incipient current of research on the labor process, influenced by Panzieri (1976), the first Touraine (1966), Braverman (1974), and Burawoy (1979), although we found his Mexican version too structuralist for our taste. But our analysis could not ignore the fact that the economic and productive system was changing. We decided to organize a seminar with a large group of young people with concerns similar to our own, with the aim to study some of the novel theories that attempted to explain the great crisis of the 1970s that had spawned a new and still-emerging model. These theories initially included French regulationism [Lipietz (1994), Coriat (1989), Boyer (1988)], the Neo-Schumpeterians [Dosi, et al. (1988), Freeman (1988)], and the flexible specialization of Piore and Sabel (1990). Our study later expanded to industrial governance (Campbell, 1991), value chains and clusters (Gereffi and Korzeniewicz, 1994), production models (Boyer and Freyssenet, 2001), technological learning (Argyris and Schon, 1978), and later the information economy (Noroya and Takeuchi, 1995). For many this was a foundational seminar, in which several of the current leaders had been trained in what we would later call New Labor Studies. However, the seminar was not simply for the purpose of adopting new theoretical frameworks such as those mentioned but also to critically analyze them. From the start, the theories were criticized for their structuralism, which ignored the role of the subjects in the reorganization processes and therefore few mentioned the concept of strategy. We also critiqued their functionalism regarding the relation between the accumulation regime and the regulatory mode. For example, they assumed an evolution from Fordism to post-Fordism or from the large to the small company in industrial districts. They also took an overly optimistic view regarding the future of labor, portraying post-Fordism as concerted flexibility, the technological revolution as creativity and freedom from unpleasant tasks, and industrial districts as the triumph of the small over the large corporations. Nevertheless, the process transformed our perspective so that we began to look at the technological, organizational and labor relations spheres and the workforce profile in the company, together with issues related to immediate ties such as clusters, clients-suppliers, and (state macroeconomic) mediating factors. But we did so without forgetting the actors. In other words, the actors and not the structures were the sources of action and decision-making, but within complex structural frameworks that were in transformation at the time. In the relationship among structures such as those mentioned and subjects' meanings and actions, the future was constructed. Therefore, while certain trends existed, they solidified through practice; the future direction could be multiple, among a set of possibilities in the specific moment, without being infinite. To analyze the subject of workers at this level, short-scope theories were not enough, and it was necessary 
to recur to more abstract concepts, to the great social theories. The issues of debate in the grand theories of our times (Marxism, structuralism, hermeneutics, rational choice, to name a few) have always been present in Latin American polemics regarding labor, in particular the question of how labor subjects are constituted. In the 1990s these concerns would lead a segment of the New Labor Studies community to delve deeper into interrogating the subjectivity of social actors, and meaning making.

Productive restructuring - a term that encompassed technological and organizational issues, labor relations, workforce profile, company cultures, and companies' relations with their surroundings - had begun in practical terms in Mexico in the early 1980s. It started with the construction of the new automotive plants in the northern region oriented toward exportation to the United States, such as Ford, GM, Chrysler, and Nissan. These plants had new technology, flexible forms of organization and labor relations, and different skill levels and supposedly different labor cultures than in the old plants of the import-substitution period located in Central Mexico. With these theoretical tools we tried to find alternative labor subjects, as a result of industrial restructuring, in the old labor class.

The other emerging sector was the maquiladora export assembly-plant sector, which, while born years earlier, really took off during this period until, in the 1990s, it became the centerpiece of manufacturing in Mexico. This sector is made up of plants that subcontract internationally for the purpose of assembling final products, primarily in the electronic, textile, and autoparts industries. These companies, which are mostly large, extensively apply the new forms of labor organization, with competitive productivity and quality levels in the international market. The first scholar to take note of this large transformation was Harley Shaiken (1984), in his comparative study of production forms in Ford plants in Canada, the United States, and Mexico. Shaiken found a higher level of technology in the new plant in Northern Mexico. This revelation contradicted earlier theories such as that of the New International Division of Labor (Frobel 1980), according to which only labor-intensive segments of the productive process were conceivable in the Third World (corresponding to its comparative advantage).

In the new conditions characterizing the 1980s, we opened up two areas of activity: reflection and research on productive restructuring, including how it changed the working class, its transformative potential, and the link between academics and unionized workers. Over a period of ten years, we studied the major transformation imposed through the restructuring of labor and firms, and we made great efforts to take these discussions to the workers in the country's major labor unions. Sometimes we interacted with the leadership of those labor unions, and on other occasions we interacted with oppositional currents. We also established several courses to educate professors about productive restructuring. We brought together groups interested in new approaches to analyzing this important issue. Some of the academic participants in those groups are currently distinguished researchers, and other participants from the labor unions themselves played important roles in their organizations. We sought out telephone company workers, electricians, and workers in the banking, social security, and aviation sectors, as well as government employees, professors, etc. We discussed the major transformations underway with workers from all of these sectors, addressing issues of work organization and flexibility, among others. 
This process culminated with what were known as the Jalapa debates, conferences on New Labor Studies in which we challenged the old perspectives on how to study workers' movements and drew attention to labor processes and labor markets. These debates brought together hundreds of scholars and labor unionists to discuss productive restructuring, helping a new generation of labor scholars in Mexico gain experience.

\section{Consolidation of Neoliberalism (the 1990s)}

Since the early 1980s, we had begun the great adventure of establishing new institutions for research on the working class. A group made up of professors and students from various institutions dedicated ourselves to this task, and we believe we succeeded. There were many people opposed to our approach, mainly currents focused on labor movements and followers of the so-called Dependency theory. Dependency theory had emerged in the 1960s and 70s but had now begun to confront new realities in Latin America such as the substitution of military for civilian regimes and productive restructuring. These circumstances revealed its limitations in explaining new situations, leading to its progressive decline and virtual disappearance. We were able to defeat the opposing viewpoints one by one, until our perspective eventually became dominant in new research undertaken in the labor studies field. Along the way, we established the first graduate program in Labor Studies in Mexico and in Latin America in 1987, and we created the Trabajo journal in 1988. We also organized the first Latin American Congress on Sociology of Work, held in Mexico City in 1993. As a result of that Congress, the Latin American Association of Sociology of Work (Asociación Latinoamericana de Sociología del Trabajo) was created, as well as the Latin American Journal on Labor Studies (Revista Latinoamericana de Estudios del Trabajo). The 1993 Congress resulted in the almost official establishment of New Labor Studies in Latin America (Cavalcanti, 2002).

During this time, parallel to the Mexican process and initially without any contact among us, other colleagues in Latin America (Lucena in Venezuela, Urréa in Colombia, Leite in Brazil, Supervielle in Uruguay, Novick and Neffa in Argentina, and Abramo in Chile) had initiated reflections similar to our own. We gathered for the first time at a seminar in Porto Alegre, Brazil in 1988, where we realized that we had each interpreted the changes in a similar way. These exchanges continued, culminating with the first Congress on Sociology of Work. The New Labor Studies in Latin America began assimilating and critiquing the post-Fordism theories of the 1980s, which, while not sociological theories, left an explicit space for the inclusion of labor processes. Said theories had the advantage of linking production with systems of industrial relations, industrial clusters, the State institutions, and macroeconomics.

Nevertheless, they were clearly insufficient and hardly original in their approach to labor. Therefore, it became necessary to explore the current French and English Sociologies of Work, especially the debate on the labor process. In contrast with the European approaches, the New Labor Studies in Latin America are unique in that they are not contained in middle-range theories but are impacted by the polemics of the broader social theories of the time. The critique of structuralism led to that of post-Fordism theories and to the interrogation of how working class subjects are constituted. The dominant trend in 
this debate has not been constructivism, but rather theories of action that do not undervalue the concept of structure and that highlight the subjectivity and action (agency). Thereby, the New Labor Studies went from a structural emphasis with reservations to a clear interest in the subjectivity as mediators of the action.

This was true with two exceptions. First, the interest in subjectivity in the new theoretical approach was not derived from the old perspectives on workers' or labor culture but rather through the interpretive shift suffered by the theories on culture. The old theories had already been incorporated, the first when scholars began to emphasize the labor movement and the second as people began to study the preliminary restructuration, especially the new forms of organization of work. The interest in studying the subjectivity of laborers as social process of meaning making first emerged with interest in identities, in a negative form. Some of the young participants sympathized with Bauman (2002) and Sennet's (2006) theses that the instability of labor trajectories, shaped workers' life paths and even characters, fragmenting workers and limiting possibilities for collective identities, organizations, movements, and projects. These theses of loss of meaning and of all idea of future reflected the context of 1980 s postmodernism. But, at the time there was too much interest in restructuring and the possible emergence of new worker subjects different from those of the import-substitution period for postmodernism to take a firm hold among the labor researchers of Mexico and Latin America. This was part of the process of looking for a new labor class. Nevertheless, by the 1990s, neoliberalism was well established in all the countries of the region, and some intellectuals sympathized with it either explicitly, adopting neoclassical or rational choice frameworks, or implicitly, recognizing the virtues of deregulation, flexibility, and especially state withdrawal from the economy. Supposedly, these were the source of inefficiencies and corruption, in which the unions were implicated. Meanwhile, another group of intellectuals who were not won over by neoliberalism sympathized with postmodernism, especially its critique of the great subjects, organizations, projects, and all idea of future and its insistence on living in the present. All of these ideas tied into the idea, promoted by Offe (1986), that work would no longer be the central articulator of the whole of social relations, because there would be a greater heterogeneity of occupations and fragmentation of lifeworlds.

In order to further my reflections on these issues and to learn more about the British school of labor relations, I spent one year as a visiting professor at the University of Warwick in England in 1995. The labor process debate was something of the past, but I was still able to find new inspiration in this approach. It was at Warwick that the Latin American Treatise on the Sociology of Work was conceived, through which 27 authors synthesized ideas and problems related to the New Labor Studies. The corresponding book was published in the year 2000 (De la Garza 2002).

In this Treatise, we confront the idea of the end of labor. We argue that the texts that forecast this are essentially structuralist theses that attempt to deduce subjectivities and actions based on the labor structure. We believe that the process of identifying with other workers entails the abstraction of differences, which may occur through practices but is nurtured in subjectivity. Heterogeneity of occupations has always existed, and there are always new jobs, but in the past this heterogeneity had not hindered the constitution of collective subjects. Nevertheless, some academics and unionists continued to attempt to 
construct a union strategy around negotiating production, on the premise that the primary terrain of the struggle had shifted to the production processes.

We also conducted research to produce a more complete map of the production models ${ }^{2}$ established since the previous decade. A debate emerged on this subject inside $\mathrm{New}$ Labor Studies. It sought to challenge the optimistic position on the direction of the productive restructuring initiated in the 1980s (when we thought new labor subjects were emerging), which in a very evolutionary way suggested that the market purified companies in ways also favorable to labor (promoting better productivity, better qualification, and better wages in the future). The latter position drew, in particular, from Gereffy's and Korzeniewicz theses (1994) of value chains, upgrading, and the full package. According to this theory, the beginning of simple assembly manufacture, as in the maquiladoras, would lead toward more sophisticated forms of production over time, because low wages could no longer sustain competitiveness. As a result, companies would move toward the full package, encompassing all phases from design to final product manufacture, resulting in higher value added. When applied to export maquilas, these theses generated the hypothesis that the sector had three stages: labor-intensive assembly, assembly using new forms of labor organization, and sophisticated, service-oriented industry dedicated to activities such as engine design for export to the United States.

\section{The Crisis of the Neoliberal Model in Mexico}

By the year 2000, the Neoliberal economic model in Mexico had started to have problems (it had already had troubles in the financial sphere in 1995 but apparently had overcome these). The first phase of this crisis was relatively mild, between 2001 and 2003, followed by a very profound crisis in 2009 . Now, the crisis was not just financial but also in production: a crisis of inability to increase productivity, given the characteristics of the dominant models of production, or productive configurations. An initial study in the maquilas (De la Garza 2003) revealed that Gereffi's predictions were not coming true. There were very few roboticzed or highly automated maquiladoras, and even fewer dedicated to sophisticated services. Instead, the predominant models were characterized by low-skilled, labor-intensive processes but broad use of new forms of labor organization. The limits on production came from the comparative advantage of low wages and skills, resulting in a workforce that, while easy to substitute, lacked motivation due to the limited career possibilities, low skill levels, and routine tasks. In turn, there was a very high voluntary turnover rate, and it was difficult to generate a culture favorable to productivity and quality. This scenario contributed to narrow profit margins highly sensitive to small fluctuations in real wages, and particularly in the exchange rate, given that, as part of the international production chains, production costs were calculated in dollars. The data illustrated the stagnation and even decline of productivity rates in the first years of this century. They showed that the dominant production model in this sector was a combination of Fordism and Taylorism with new forms of labor organization, high labor intensification, no cutting edge technology, low skill levels and wages, and high turnover (De la Garza, 2007). 
The need to broaden these conclusions to the whole productive apparatus took me to Berkeley, California, in 2004 where I completed the research, with very similar results. In other words, it was probable that the dominant production models under neoliberalism in Mexico had reached the limit of their ability to increase productivity. These predictions were affirmed in the great crisis of 2009, when GDP fell 6.7\% in real terms (De la Garza, 2006).

In the same year the Treatise was published, 2000, a group of important academics and unionists founded the Institute for Labor Studies (Instituto de Estudios del Trabajo), one more effort in the long history of attempts to link labor with academia, this time through seminars and conferences, research, training unionists, and publishing books. We have produced several important publications, in particular, ten volumes on Productive Restructuration and Union Policies, which analyze key sectors of the economy. Especially noteworthy are the two versions of La Situación del Trabajo en México ('The Labor Situation in Mexico') that emulate their North American counterpart, the State of Working in America, by the Economic Policy Institute. The AFL-CIO provided support for both of these projects.

In recognition of the especially important influence of Bauman (2004) in Latin America in the early years of the current century, in particular among students, we began a systematic critique of his work. We also started in 2007 a study among workers who we initially referred to as atypical, in keeping with the new European concept. We abandoned the term along the way, given that the atypical is in fact very typical in our region and the fact that it failed to get to the heart of what we wanted to discuss - the possibility of collective action and identity among workers from apparently fragmented trajectories and occupations. That term, rather, focused on the distance between labor rights (sometimes seen as citizenship rights) and the rise of informal jobs in developed countries. As part of this effort, we pursued empirical research in Mexico City among workers such as street vendors, ranging from ambulant salespeople to those with fixed locations on sidewalks and in the subway system; minibus, metrobus and taxi drivers; Walmart and McDonald's employees; television extras, and call center operators. We worked from an understanding of labor that could not be reduced to the material but rather included immaterial work, combining production, circulation, and consumption in one sole act, as in a theater play. We also attempted to delve into the symbolic aspects of work. All work, even that with the most concrete products, entails symbolic aspects, such as work objects, means of production, and the product itself, in addition to the interaction between workers and the means of production. Nevertheless, the symbolic aspects may vary widely, to the point that we can speak, in certain cases such as software design, of purely symbolic production. Furthermore, the issue of work space is highly relevant in work carried out in the street, a public space that allows workers to interact with clients but also with many other subjects who coexist with the labor activity without particular interest in it, such as passersby, police officers, inspectors, motorists, neighbors, etc. These circumstances may compel us to expand concepts like labor control, labor relations, and the social construction of occupations to include triadic or multiple relations in different cases. This will help revise the current concept of labor relation, reduced to the relation between capital and labor, which originated in the nineteenth century in the context of particular social relations of production. 
With the rise of industrial production, it would seem logical that the concept of labor relations would focus on the wage relation between two actors. However, if we return to the basic definition, labor relations are the social interactions that occur between actors in the production process and thereby are not reducible to relations of dependence. A similar argument could be made in the case of the concepts of control over work and on the social construction of occupations, especially in cases including more than two actors.

It has also been interesting, in this research, to explore the forms of identity among these types of workers. These workers' identities are not reduced to identifying with the product, as an unpleasant aftertaste of certain jobs, but rather reflect the workers' identification with their labor community and in some cases their organizations. Community identity is most visible in the response to threats or external enemies that may threaten the occupation itself and that lead workers to organize and often to pursue collective actions. Such pressures reveal an informal world full of work-related effervescence, strong identities, and a high level of organization and conflict. The fragmentation of careers was thus not enough to avoid workers' identities. Identification with trajectories may also exist, as in migrant groups, and face-to-face interaction among workers is not a necessity. Reducing identity to the homogeneity of occupations is based in an outdated history of trade workers and trade unions, dating to the emergence of Taylorism and Fordism. In addition, it has a structuralist connotation that reduces identity as a form of subjectivity to a hypo-phenomenon of the structure of occupations. Furthermore, a 'solid' identity is not necessarily a prerequisite for social movements, which may emerge around ambiguous identifications and highly sensitive points of ignition.

\section{Final Reflections}

In my life I have experienced many precarious situations, which I have been able to work around or even reverse thanks to my view of life as an arena of struggle - just like my childhood friends did in their imaginary battles. But, I have also been able to persist because of the fact that, throughout my engagement in the struggles of the era, I never ceased to study. Ultimately, knowledge expands my freedom. I have no regrets - not for having studied engineering, not for my political activism, and certainly not for the rich academic life I have experienced and that has brought me great satisfactions. I confess that I've lived, I've loved and hated, I've destroyed and built, and I will continue to do so, although not in conditions of my choosing. I cannot imagine any other way of living. Anyway, we are here today amidst an economic and productive crisis that reveals the limits of the current production model, but points to few subjective possibilities: unions with no alternative project, and the same scenario among opposing political forces; academics and students who have lost meaning; and in the end, a labor movement that is unable to

achieve a new union between feeling and thinking. Anyway, we continue looking for the lost labor subject 


\section{NOTES}

1. The concept of Neoliberalism is not well received by certain academics, in part because it is used as an adjective instead of a noun. Here we conceive of it as the model that at the international level, around the late 1980s substituting the economic-intervention model, referred to as the benefactor, Keynesian, or social state model. This is not to deny that it has several modes (Southeast Asia, Northern Europe, Continental Europe, the Anglophone regions, Latin America, China, India, etc.), but there is no doubt that important changes took place starting with the great crisis of the second half of the 1970s. We define a Neoliberal Socioeconomic Formation as the configuration of a social doctrine that assumes each person makes individual decisions guided by cost/benefit calculations. This doctrine was extended from economics to the whole of social relations, and its ideological counterpart is the idea that each person's common sense operates individually through personal effort with no need for state intervention. The second dimension of Neoliberalism is as economic theory and policy, the first derived from neoclassic assumptions, translated into policy, that equilibrium will be spontaneously achieved in the absence of exogenous factors and market failures. Important implications for economic policy include the deregulation of markets, in particular the labor market, which can now be organized through flexibility. Neoliberalism has also been historically associated with new configurations of production around flexibility. It also implies a transformation of the Keynesian role of the State, shifting from producer toward overseer of monetary circuits and from benefactor and protector to deregulator of the labor market, labor legislation, and social security (see Enrique de la Garza 2000) La Formación Socioeconómica Neoliberal. Mexico City, Plaza y Valdés-UAM. English version may be consulted at: http://docencia.izt.uam.mx/egt

2. In the mid-1990s, the concept of production model was adopted to refer to a particular combination of business strategies with technology, organization, labor relations, and the workforce. But the concept was transformed, first because it became applied to management and labor cultures, and second because people saw the model of production simply from the structural framework in which labor or management subjects negotiate or confront each other, such that the business strategies always ended up incomplete and limited to one typology. On the other hand, some people proposed to study the constitution of strategies, stripping them of their rationalist connotation by envisioning them as sphere of subjectivity that included scientific reason or calculation but that was not limited to these categories. This way, strategizing constituted a problem that could not be deduced from the productive model. On the other hand, some questioned the systemic and highly functionalist character of the concept and proposed to interrogate contradictions, looking at causal relations together with weak relations permeated by culture, discontinuities, and problems resolved in the practice. Therefore, socio-technical configuration appeared to be a more adequate concept than mode of production.

${ }^{*}$ Complete texts may be consulted at http://docencia.izt.uam.mx/egt. 


\section{REFERENCES}

Aglietta, M. (1994) A Theory of Capitalist Regulation. London: New Left Review.

Argyris, C. and D.A, Schon (1978) Organizational Learning. Massachusetts: Adison Wesley Reading.

Bauman, Z. (2002) Identity. Cambridge: Polity Press

Bauman, Z. (2004) Modernidad Liquida. Mexico City: Fondo de Cultura Económica.

Boyer, R, and M. Freyssenet (2001) Los Nuevos Modelos Productivos. Buenos Aires: Humanitas.

Boyer, R. (1988) 'Alla Ricerca di Alternative al Fordismo', Stato e Mercato, Milano, no. 24.

Braverman, H. (1974) Labor and Monopoly Capitalism. N.Y.: Monthly Review Press.

Burawoy, M. (1979) Manufacturing Consent. Chicago: University of Chicago Press,

Calvalcanti, H.B. (2002) 'Sociology of Work in Latin America', Work and Occupations 29(1): 5-31.

Campbell, J.C. (1991) Governance of American Economy. London: Cambridge University Press.

Castoriadis, C. (1979) La Experiencia del Movimiento Obrero. Barcelona: Tusquets.

Coriat, B. (1989) L'atellier et le Robot. Paris: Bourgois.

De la Garza, E. (1982) El Otro Movimiento Estudiantil. Mexico City: Extemporáneos. [Complete texts may be consulted at http://docencia.izt.uam.mx/egt]

De la Garza, E. (1988) Ascenso y Crisis del Estado Social Autoritario. Mexico City: El Colegio de México. [Complete texts may be consulted at http://docencia.izt.uam.mx/egt]

De la Garza, E. (2003) Modelos de Producción en la Maquila de Exportación. Mexico City: Plaza y Valdés-UAM. [Complete texts may be consulted at http://docencia.izt.uam.mx/egt] 
De la Garza, E. (2006) Empresas y Trabajadores en México al Inicio del Siglo XXI. Mexico City: Fondo de Cultura Económica. [Complete texts may be consulted at http://docencia.izt.uam.mx/egt]

De la Garza, E. (2007) 'The Crisis of the Maquila Model in Mexico', Work and Occupations 34(4): 399-429.

De la Garza, E. (coord.) (2000) Tratado Latinoamericano de Sociología del Trabajo. Mexico City: Fondo de Cultura Económica. [Complete texts may be consulted at http://docencia.izt.uam.mx/egt]

Dosi, G, et al. (1988) Technical Change and Economic Theory. London: Printer.

Freeman, C. (1988) 'Structural Crisis and Adjustment, Business Cycles and Investment Behaviour' in Dosi, G. et al, Technical Change and Economic Theory. London: Printer.

Frobel, C. (1984) The New International Division Of Labour. London: Cambridge University Press.

Gereffi, G. and M. Korzeniewicz (1994) Commodity Chains and Global Capitalism. N.Y.: Praeger Publishers.

Nonaka, I. and H. Takeuchi (1995) The Knowledge Creating Company. N.Y.: Oxford University Press.

Offe, C. (1996) Disorganised Capitalism. Cambridge: Polity.

Panzieri, R. (1976) 'Acerca del Uso Capitalista de la Máquina', La División Capitalista del Trabajo, México, D.F.: Siglo XXI.

Piore, M. and Ch. Sabel (1990) La Segunda Ruptura Industrial. Madrid: Alianza Editorial.

Schmitter, Ph.C. (1974) 'Still the Century of Corporatism', The Review of Politics 36(1): 85-131.

Sennet, R. (2006) The Culture of the New Capitalism. New Haven: Yale University.

Shaiken, H, (1984) Work Transformed. N.Y. : Holt-Rinehart-Winston.

Touraine, A. (1966) La Conscience Ouvrière. Paris: Editions du Seuil. 


\section{BIOGRAPHICAL NOTE}

Enrique de la Garza Toledo is Professor of the graduate program in Labor Studies at the Metropolitan Autonomous University of Mexico (UAM). [Full texts may be consulted at http://docencia.izt.uam.mx/egt.] 